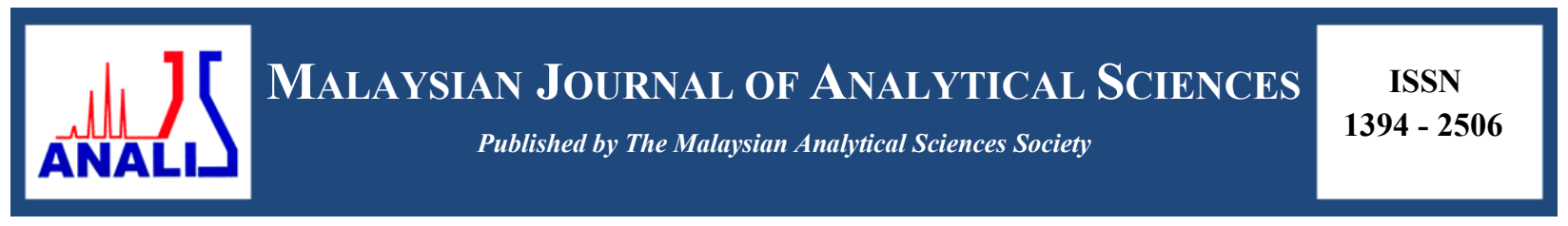

\title{
SALTWATER INTRUSION ANALYSIS IN EAST COAST OF TERENGGANU USING MULTIVARIATE ANALYSIS
}

\author{
(Analisis Pencerobohan Air Masin di Kawasan Pantai Timur, Terengganu Menggunakan \\ Analisis Multivariat)
}

\author{
Norsyuhada Hairoma ${ }^{1}$, Muhd Barzani Gasim ${ }^{1,2}$, Azman Azid $^{1,2}$, Haniff Muhamad $^{1}$, Nur Hishaam Sulaiman ${ }^{1}$, \\ Zuriati Khairuddin ${ }^{1}$, Ahmad Dasuki Mustafa ${ }^{1}$, Fazureen Azaman ${ }^{1}$, Muhammad Azizi Amran ${ }^{1}$ \\ ${ }^{1}$ East Coast Environmental Research Institute (ESERI), \\ Universiti Sultan Zainal Abidin, Gong Badak Campus, 21300 Kuala Terengganu, Terengganu, Malaysia \\ ${ }^{2}$ Faculty Bioresources and Food Industry, \\ Universiti Sultan Zainal Abidin, Tembila Campus, 22200 Besut, Terengganu, Malaysia
}

*Corresponding author: nsyuhadahairoma@gmail.com

Received: 14 April 2015; Accepted: 3 August 2016

\begin{abstract}
Coastal aquifer groundwater is vulnerable to saltwater contamination as it is located near the coastline. Therefore, a study is conducted to confirm all the major source of pollutants on coastal groundwater based on 13 sampling wells that located close to Terengganu coastline as well as to assess the intensity of saltwater intrusion into the wells. Measurements of selected water quality parameters such as dissolve oxygen (DO), electrical conductivity (EC), total dissolve solid (TDS), salinity, $\mathrm{pH}$, turbidity and total suspended solid (TSS) were obtained from each well by using certified scientific instruments. Data were analysed by using multivariate techniques which involves principle component analysis (PCA) and cluster analysis (CA). CA was performed by using hierarchical agglomerative cluster analysis (HACA) technique. PCA yielded two PCs where PC1 forms composite factor loadings of TDS, salinity and EC that represented the saltwater intrusion meanwhile, PC2 formed composite factors of turbidity, TSS and TDS that represented the anthropogenic pollutions. CA successfully classified sampling wells into seven clusters; Extreme High (EH), Very High (VH), High (H), Moderate (M), Low (L), Very Low (VL) and Extreme Low (EL) where each cluster represented the saltwater intrusion intensity in decreasing order.
\end{abstract}

Keywords: groundwater, coastal aquifer, saltwater intrusion, multivariate techniques

\begin{abstract}
Abstrak
Air bawah tanah dari akuifer pantai terdedah kepada pencemaran air masin kerana ia terletak berhampiran pantai. Oleh itu, satu kajian dijalankan untuk mengesahkan sumber utama pencemaran kepada air bawah tanah pantai berdasarkan 13 telaga pensampelan yang terletak berhampiran kawasan pantai Terengganu serta untuk menilai keamatan pencerobohan air masin ke dalam telaga.Pengukuran parameter kualiti air seperti oksigen terlarut (DO), kekonduksian elektrik (EC), jumlah pepejal terlarut (TDS), kemasinan, $\mathrm{pH}$, kekeruhan dan jumlah pepejal terampai (TSS) diambil dari setiap telaga dengan menggunakan peralatan saintifik. Data dianalisis menggunakan teknik multivariat iaitu analisis komponen utama (PCA) dan analisis kelompok (CA). CA dilakukan menggunakan teknik analisis kelompok hierarki agglomeratif (HACA). PCA menghasilkan dua PC yang mana, PC1 membentuk faktor komposit TDS, kemasinan dan EC yang mewakili pencerobohan air masin manakala, PC2 membentuk faktor komposit kekeruhan, TSS dan TDS yang mewakili pencemaran antropogenik. CA berjaya mengelaskan telaga pensampelan kepada tujuh kelompok; Tinggi Ekstrem (EH), Sangat Tinggi (VH), Tinggi (H), Sederhana (M), Rendah (L), Sangat Rendah (VL) dan Rendah Ekstrem (EL) yang mana setiap kelompok mewakili keamatan pencerobohan air masin dalam urutan berkurangan.
\end{abstract}




\section{Norsyuhada et al: SALTWATER INTRUSION ANALYSIS IN EAST COAST OF TERENGGANU USING MULTIVARIATE ANALYSIS}

Kata kunci: air bawah tanah, akuifer pantai, kemasukan air masin, teknik multivariat

\section{Introduction}

Water plays a critical role in human life because human need water to stay alive and to carry out daily activities either as in domestic uses or economic uses. As human population keeps growing over times, the demands for water keep increasing as well. For Malaysia, it is a tropical country and thus, receiving an adequate amount of rainfall throughout the year. Supposedly, available water should be enough to cater the needs of its people. However, there are still some states that are experiencing a water shortage crisis [1]. Another alternative for freshwater supply is from groundwater. Groundwater is defined as subsurface water and can be either stored in confined or unconfined aquifer. These aquifers can be distinguished by the water components and type of surface and subsurface water interaction [2]. Water stored as groundwater is originated from surface water that seep slowly into the ground. It takes a long time to fill up the groundwater storage. In contrast, groundwater can be extracted easily by drilling a well into aquifer. Extraction of groundwater without a proper management may lead to imbalance rate of recharge and discharge. As a result, it causes threat to this valuable water resource.

Besides, groundwater aquifer is also vulnerable to saltwater contamination [3]. This kind of threat is generally related to aquifers that located close to coastline. These aquifers are known as coastal aquifers. Theoretically, freshwater and saltwater are of different density and thus, these waters should not mix up. Instead, freshwater and saltwater was separated by a zone known as transition zone containing brackish water. This zone kept freshwater and saltwater in natural equilibrium $[4,5]$. The location of the transition zone is not fixed as it is can either move further inland or towards the sea depending on several factors. The movement can be map or visualize by adopting hydrogeochemical and geophysical technique [6]. In a normal condition, freshwater will be flowing into the sea. A reversed situation can occur where the saltwater is flowing into the freshwater under the influences of natural events and anthropogenic activities [7 - 9].

This unfavourable situation caused a great concern to peoples living along the coast since long time ago. This is because of a further movement of saltwater toward the land will lead to saltwater intrusion into coastal aquifer that containing their main freshwater supply [7 - 11]. Contamination of $2-3 \%$ of saltwater into coastal aquifer will increase the waters salinity and resulting in water quality degradation [8]. This problem is also experienced by residence living along Terengganu coastline which is the area of this study. Most of the residents in this area still use groundwater withdrawn from the drilled wells. Some of them use the water only for basic uses such as for watering crops and livestock drinking water. The rest of them used the well water as their main water supply due to financial issues. In conjunction to this problem, a study is carried out to confirm the major sources of groundwater quality pollutants based on sampling wells that located along Terengganu coastline and to assess the intensity of saltwater intrusion into the wells.

\section{Study area}

\section{Materials and Methods}

Terengganu is located on the east coast of Peninsular Malaysia [12]. Specifically, it is located between longitudes $102.25{ }^{\circ} \mathrm{E}$ to $103.50^{\circ} \mathrm{E}$ and latitude $4 \mathrm{~N}$ to $5.50^{\circ} \mathrm{N}$. The size of Terengganu is approximately $1,295,638.3$ hectares with coastline bordered by South China Sea and stretching $225 \mathrm{~km}$ from Besut to Kemaman [12]. It received an average rainfall of $\pm 400 \mathrm{~mm}$ per annum during the northeast monsoon season from November to March, meanwhile $\pm 190 \mathrm{~mm}$ per annum during the other months $[12,13]$. Its average temperature is from $29{ }^{\circ} \mathrm{C}$ to $32{ }^{\circ} \mathrm{C}$ throughout the year [14]. Sampling areas were located along the Terengganu coastline (Figure 1).

Generally, Terengganu coastline is dominated by Quaternary rock of marine and continental deposits [15]. It is specifically known as Holocene beach ridges derived from Matang Gelugor Member. It is comprises of sand, gravel and sandy clay deposits in littoral and marine environment [16, 17]. In the hydrogeology perspective, Quaternary sediment is characterized by high porosity and excellent permeability that allowed water to be stored in between the grains [18]. Carboniferous rock and minor intrusive rock also present along the centre and south of Terengganu coastline. 

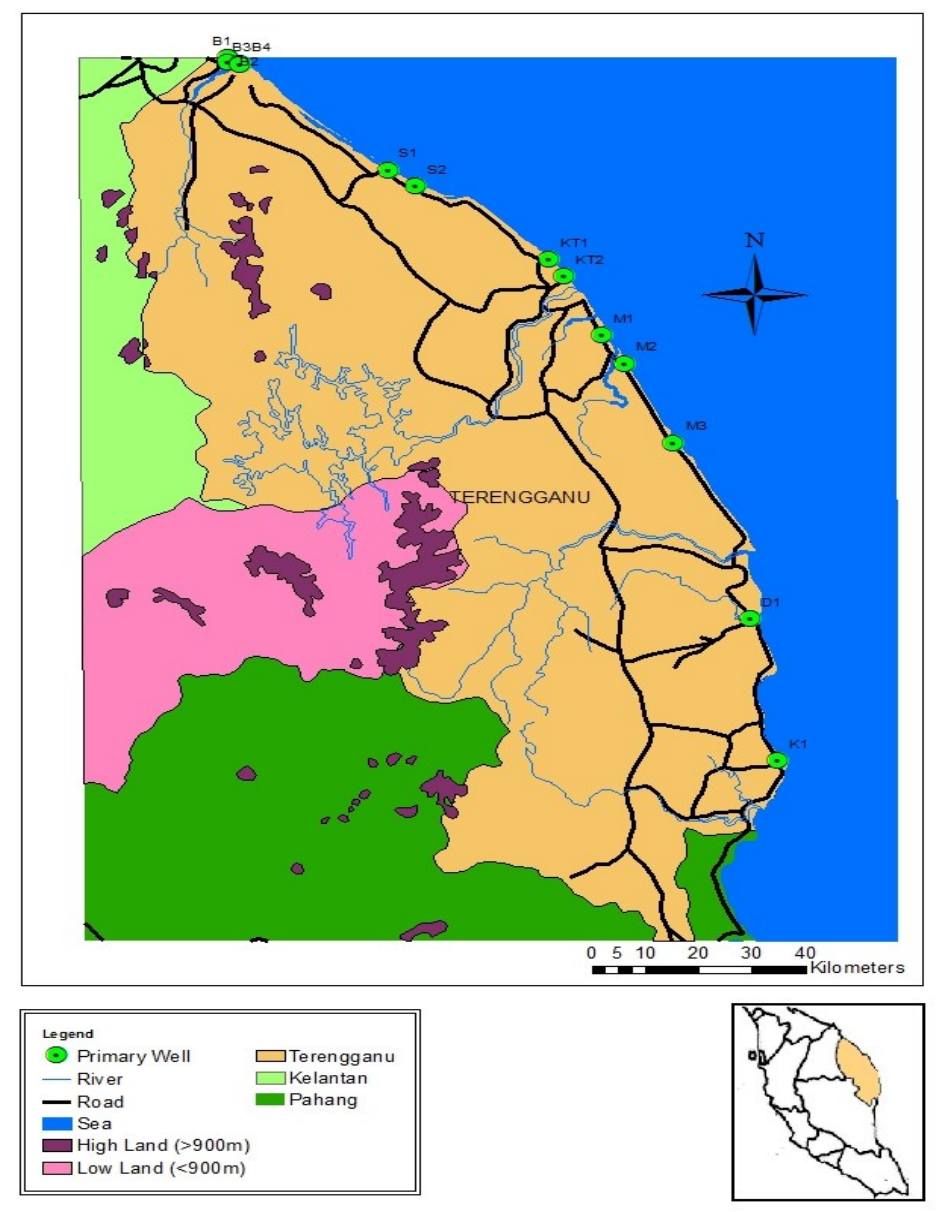

Figure 1. Location of sampling wells (Primary Well) along Terengganu coastline

\section{Data collection}

Samplings were carried out at 13 private wells, located closely to Terengganu coastline from July to August 2015 (Table 1). Samplings were conducted monthly by performing in situ measurements of selected water quality parameters such as dissolve oxygen (DO), electrical conductivity (EC), total dissolve solid (TDS), salinity, $\mathrm{pH}$, turbidity and total suspended solid (TSS) . DO, EC, TDS, salinity and $\mathrm{pH}$ were measured using YSI 556 Handheld Multiparameter meter. Turbidity was measured using 2100Q Portable Turbidimeter and TSS was measured using HACH DR 900 Multiparameter Handheld meter. Global Positioning System (GPS) was used to locate the exact coordinates of sampling wells.

\section{Multivariate analysis}

A numbers of physiochemical parameters can be used to determine the groundwater quality namely total dissolve solid (TDS), dissolve oxygen (DO), total suspended solid (TSS), salinity, electrical conductivity (EC), chloride, biochemical oxygen demand (BOD) and $\mathrm{pH}$ value. However, it is difficult to define the main factors that control groundwater quality since there are too many data. Multivariate analysis such as principal component analysis and cluster analysis is suggested to be one of the best solutions to re-define the meaning of a mass of data. Therefore, multivariate analysis is employed to achieve the objective of this study. 


\section{Norsyuhada et al: SALTWATER INTRUSION ANALYSIS IN EAST COAST OF TERENGGANU USING MULTIVARIATE ANALYSIS}

Table 1. Coordinate location of sampling wells

\begin{tabular}{lcc}
\hline Sampling Well & Latitude & Longitude \\
\hline B1 & $5.8339^{\circ}$ & $102.5553^{\circ}$ \\
B2 & $5.8241^{\circ}$ & $102.5566^{\circ}$ \\
B3 & $5.8216^{\circ}$ & $102.5754^{\circ}$ \\
B4 & $5.8202^{\circ}$ & $102.5774^{\circ}$ \\
S1 & $5.5951^{\circ}$ & $102.8262^{\circ}$ \\
S2 & $5.5605^{\circ}$ & $102.8736^{\circ}$ \\
KT1 & $5.4039^{\circ}$ & $103.0992^{\circ}$ \\
KT2 & $5.3686^{\circ}$ & $103.1241^{\circ}$ \\
M1 & $5.2435^{\circ}$ & $103.1872^{\circ}$ \\
M2 & $5.1825^{\circ}$ & $103.2256^{\circ}$ \\
M3 & $5.0135^{\circ}$ & $103.3096^{\circ}$ \\
D1 & $4.6387^{\circ}$ & $103.4383^{\circ}$ \\
K1 & $4.3361^{\circ}$ & $103.4858^{\circ}$ \\
\hline
\end{tabular}

\section{Principal component analysis (PCA)}

PCA identify the principle components (PCs) of data sets by transforming the original variables into new variables [19 - 23]. The input data matric (variables $\mathrm{x}$ cases) used for this method was [7 $\mathrm{x}$ 52]. PCs with eigenvalues more than 1.0 computed from PCA process is considered as significant PCs. These PCs were then rotated and the count of PCs was used as rotation factor in varimax normalization process. Two significant varifactors (VFs) of eigenvalues more than 1.0 explaining $67.44 \%$ of the total variance of water quality data set were yielded [24]. Each VF contains a list of factor loadings that explains the major sources of groundwater pollutant.

\section{Cluster analysis (CA)}

Cluster analysis is technique for data classification based on their similarities or closeness [22, 23, 25]. It is done by performing hierarchical agglomerative cluster analysis (HACA) on selected parameters spatially or temporally. In this study, spatial cluster analysis is applied onto selected parameters to group the sampling wells into a few clusters. Sampling wells that grouped as a cluster are homogenous to each other meanwhile, sampling wells between clusters were heterogeneous.

\section{Identification of source of pollutant}

\section{Results and Discussion}

Corresponding VFs, loadings and variance resulted from PCA are presented in Table 2. Bolded values in Table 2 indicated the strong and moderate factor loadings with absolute loading values of $>0.75$ and $0.75-0.50$, respectively. These factor loadings were considered as important factors that influence water quality [26]. The unbolded values represent the weak factor loadings with absolute loading values of $0.50-0.30$ and have minor contribution for this water quality study.

VF1, explaining $48.66 \%$ of total variance, has strong positive loadings on EC, TDS and salinity. This composite factor represents the saltwater intrusion into coastal aquifer. These factors combination proposed that the dissolved solid engaged in PC1 was dissolved salts supplied by high salt contents of seawaters through saltwater intrusion process. Thus, it can be emphasized that groundwater samples from study area are highly susceptible to saltwater intrusion as it is located near to coastline. 
Table 2. Factor loadings after Varimax rotation from PCA of sampling wells.

\begin{tabular}{lcc}
\hline Variables & VF1 & VF2 \\
\hline Turbidity (NTU) & -0.281 & $\mathbf{0 . 7 4 3}$ \\
TSS & 0.273 & $\mathbf{0 . 5 7 7}$ \\
DO $(\mathrm{mg} / \mathrm{L})$ & -0.109 & $\mathbf{- 0 . 5 9 8}$ \\
EC $\left(\mathrm{mS} \mathrm{cm}\right.$ c $\left.^{-1}\right)$ & $\mathbf{0 . 9 5 6}$ & -0.035 \\
TDS $(\mathrm{mg} / \mathrm{L})$ & $\mathbf{0 . 9 7 5}$ & 0.0004 \\
Salinity $(\mathrm{ppt})$ & $\mathbf{0 . 9 7 6}$ & -0.002 \\
pH & 0.649 & -0.259 \\
Eigenvalue & 3.424 & 1.297 \\
\% Total variance & 48.66 & 18.78 \\
Cumulative \% variance & 48.66 & 67.44 \\
\hline
\end{tabular}

Values in bold indicate strong and moderate loadings

VF2, explaining $18.78 \%$ of total variance, has positive moderate loading on turbidity, positive moderate loading on TSS and negative moderate loading on DO. This composite factor is proposed to represent the anthropogenic pollution such as waste dumping into wells. The small suspended solid originated from the waste act like a barrier for the direct light entering the wells. It would be able to reach the well base only by scattering through the small spaces in between the particles. The measure of amount of light scattered of these particles is known as turbidity. This explains the association of total suspended solid with turbidity. If the amount of total suspended solid is high, the turbidity would be high as well. In contrast, increasing amount of turbidity and total suspended solid has inverse relationship with dissolved oxygen. The oxygen is suggested to be used up by microorganism for decay process [27].

\section{Spatial clustering}

A further analysis on saltwater intrusion which was identified from the VF1 composite factor is done by applying spatial clustering. Parameters included in VF1 composite factor are EC, TDS and salinity. The aim of this application is to cluster the sampling wells according to the range of EC, TDS and salinity readings. Results of this analysis revealed six main clusters. The results of cluster analysis of each parameter are shown in Figures 2, 3 and 4 , respectively. Interestingly, all parameters have classified the sampling wells into seven statistically significant clusters. The count and the sampling wells listed under each cluster were also similar. As stated before, EC, TDS and salinity were related to each other. Therefore, it could explain why sampling wells that listed below each cluster is the same for all parameters.

The result of EC, TDS and salinity cluster analysis is suggested to represent the intensity of saltwater intrusion and is shown as a summary in Figure 5. Overall, CA revealed that sampling well B3 is intruded by extremely high (EH) saltwater intrusion compared to other stations followed by very highly $(\mathrm{VH})$ intruded well B4, highly $(\mathrm{H})$ intruded well KT1, moderately (M) intruded well B1, low or less (L) intruded well M3, and very low (VL) intruded well S2, KT2, M1 and D1. EH cluster is characterised by extremely high EC $(3965.25 \mu \mathrm{S} / \mathrm{cm})$, extremely high TDS $(2384.5$ $\mathrm{mg} / \mathrm{L})$ and extremely high salinity (1.89 ppt) compared to other clusters. VH cluster has very high EC (1278.6 $\mu \mathrm{S} / \mathrm{cm})$, very high TDS $(1161.88 \mathrm{mg} / \mathrm{L})$ and very high salinity $(0.905 \mathrm{ppt})$.

$\mathrm{H}$ cluster has high EC $(1094.75 \mu \mathrm{S} / \mathrm{cm})$, high TDS $(608.05 \mathrm{mg} / \mathrm{L})$ and high salinity $(0.52 \mathrm{ppt})$. M cluster is characterised by moderate EC $(556.25 \mu \mathrm{S} / \mathrm{cm})$, moderate TDS $(326.14 \mathrm{mg} / \mathrm{L})$ and moderate salinity $(0.24 \mathrm{ppt})$. L cluster has low EC $(331.95 \mu \mathrm{S} / \mathrm{cm})$, low TDS $(175.52 \mathrm{mg} / \mathrm{L})$ and low salinity $(0.18 \mathrm{ppt})$. VL clusters has very low EC $(246.9-321.68 \mu \mathrm{S} / \mathrm{cm})$, very low TDS $(147.89-194.01 \mathrm{mg} / \mathrm{L})$ and very low salinity $(0.10-0.14 \mathrm{ppt})$. On the other hand, the least or extremely low (EL) intruded sampling wells are B2, S1, M2, K1. This cluster has extremely 
low EC (140.15 - $189.15 \mu \mathrm{S} / \mathrm{cm})$, extremely low TDS (84.34-111.96 mg/L) and extremely low salinity $(0.06-0.09$ ppt).

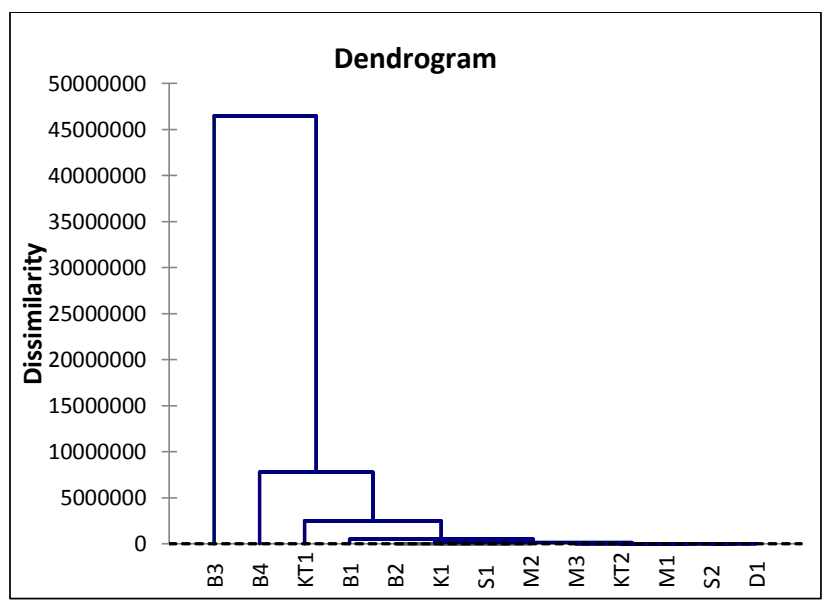

Figure 2. Dendrogram of spatial classification for EC of sampling wells along Terengganu coastline

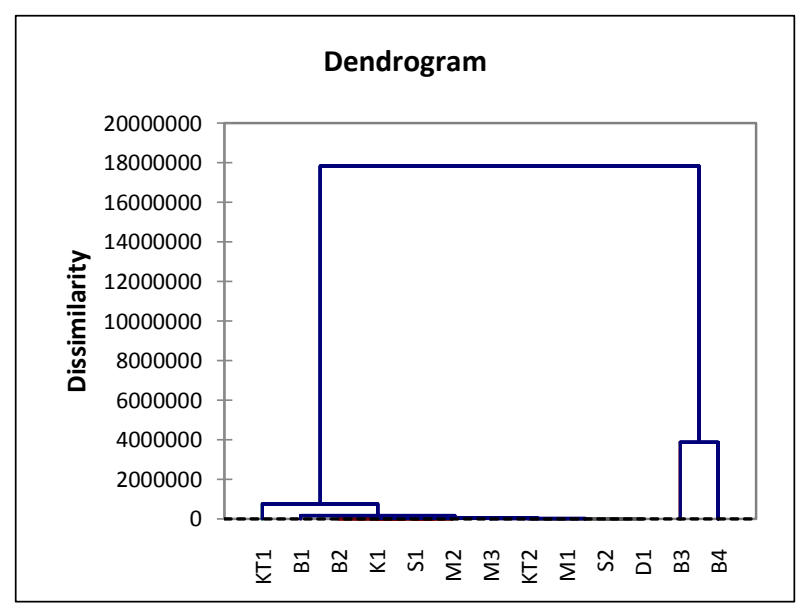

Figure 3. Dendrogram of spatial classification for TDS of sampling wells along Terengganu coastline

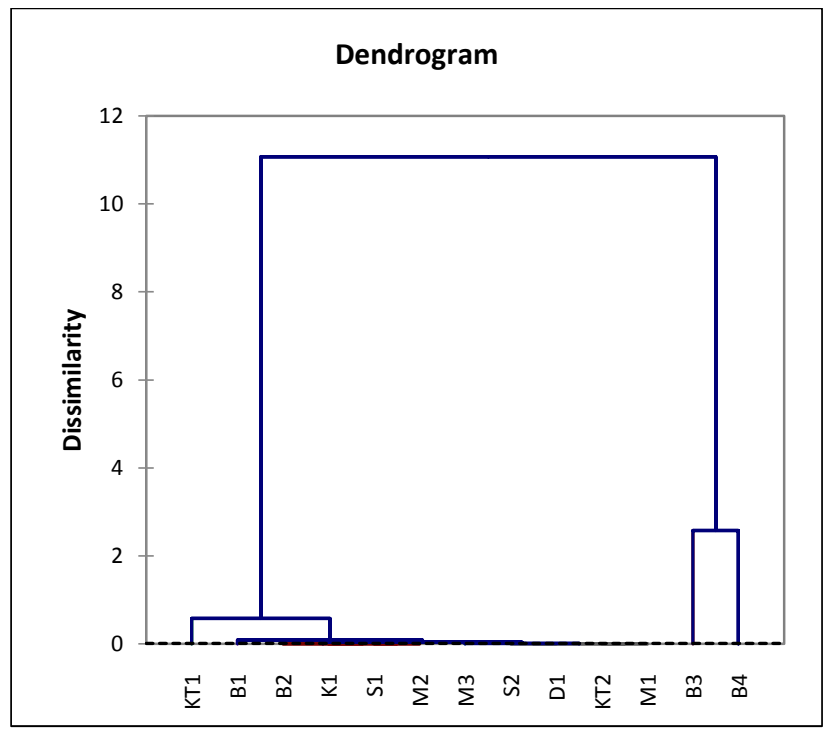

Figure 4. Dendogram of spatial classification for salinity of sampling wells along Terengganu coastline 


\begin{tabular}{|c|c|c|c|c|c|c|}
\hline \multicolumn{7}{|c|}{$\begin{array}{l}\text { Intensity of saltwater intrusion decreasing } \\
\text { (Intensity of electrical conductivity, total dissolve solid \& salinity decreasing) }\end{array}$} \\
\hline $\begin{array}{l}\text { Extremely } \\
\text { High } \\
\text { (EH) }\end{array}$ & $\begin{array}{l}\text { Very } \\
\text { High } \\
\text { (VH) }\end{array}$ & $\begin{array}{c}\text { High } \\
\text { (H) }\end{array}$ & $\begin{array}{l}\text { Moderate } \\
\text { (M) }\end{array}$ & $\begin{array}{l}\text { Low } \\
\text { (L) }\end{array}$ & $\begin{array}{l}\text { Very } \\
\text { Low } \\
\text { (VL) }\end{array}$ & $\begin{array}{l}\text { Estremely } \\
\text { Low (EL) }\end{array}$ \\
\hline B3 & B4 & KT1 & B1 & $\mathrm{M} 3$ & $\begin{array}{c}\text { S2 } \\
\text { KT2 } \\
\text { M1 } \\
\text { D1 }\end{array}$ & $\begin{array}{c}\text { B2 } \\
\text { S1 } \\
\text { M2 } \\
\text { K1 }\end{array}$ \\
\hline
\end{tabular}

Figure 5. Saltwater intrusion intensity based on EC, TDS and salinity cluster analysis of sampling well along Terengganu coastline

\section{Conclusion}

According to principle component analysis (PCA) technique, two pollutants that affect the groundwater quality of sampling wells that located along Terengganu coastline are the saltwater intrusion and the anthropogenic pollutions such as waste dumping into the wells. Next, cluster analysis performed on EC, TDS and salinity has grouped sampling wells into seven clusters; EH, VH, H, M, L, VL, EL. The extremely high (EH) intruded by saltwater is groundwater of sampling well B3 compared to other wells, very highly (VH) intruded well is B4, highly $(\mathrm{H})$ intruded is KT1, moderately (M) intruded is B1, less or low (L) intruded is M3, very low intruded sampling wells are S2, KT2, M1 and D1 meanwhile, extremely low intruded wells are B2, S1, M2 and K1.

\section{Acknowledgement}

This research is fully supported by FRGS/2/2014/STWN06/UNISZA/01/1(RR 082) research grant. The authors would like to express an appreciation to the East Coast Environmental Research Institute (ESERI), Universiti Sultan Zainal Abidin (UniSZA) for giving advice, guides, support and for the use of their research facilities.

\section{References}

1. Che-Ani, A. I., Shaari, N., Sairi, A., Zain, M. F. M., and Tahir, M. M. (2009). Rainwater harvesting as an alternative water supply in the future. European Journal of Scientific Research 34(1): 132 - 140.

2. Green, T. R., Taniguchi, M., Kooi, H., Gurdak, J. J., Allen, D. M., Hiscock, K. M., Treidel, H. and Aureli, A. (2011). Beneath the surface of global change: Impacts of climate change on groundwater. Journal of Hydrology, 405: 532 - 560 .

3. Choudhury, K., Saha, D. K., and Chakraborty, P. (2001). Geophysical study for saline water intrusion in a coastal alluvial terrain. Journal of Applied Geophysics, 46(3): 189 - 200.

4. Abdullah, M. H., Raveena, S. M., and Aris, A. Z. (2010). A numerical modelling of seawater intrusion into an oceanic island aquifer, Sipadan Island, Malaysia. Sains Malaysiana 39(4): 525 - 532.

5. Werner, A. D., Bakker, M., Post, V. E. A., Vandenbohede, A., Lu, C., Ataie-ashtiani, B., Simmons, C. T., and Barry, D. A. (2013). Seawater intrusion processes, investigation and management: Recent advances and future challenges. Advances in Water Resources, 51:3 - 26.

6. Samsudin, A. R., Haryono, A., Hamzah, U. and Rafek, A. G. (2008). Salinity mapping of coastal groundwater aquifers using hydrogeochemical and geophysical methods: A case study from north Kelantan, Malaysia. Environmental Geology, 55(8): 1737 - 1743.

7. Priyanka, B. N., and Mahesha, A. (2015). Parametric studies on saltwater intrusion into coastal aquifers for anticipate sea level rise. Aquatic Procedia, 4: 103 - 108.

8. Abd-Elhamid, H. F. and Javadi, A. A. (2011). A density-dependant finite element model for analysis of saltwater intrusion in coastal aquifers. Journal of Hydrology, 401(3): 259 - 271. 
9. Yao-Dong, D., Xu-Hua, C., Xian-Wei, W., Hui, A., Hai-Lai, D., Jian, H. and Xiao-Xuan, W. (2013). A review of assessment and adaptation strategy to climate change impacts on the coastal areas in South China. Advances in Climate Change Research, 4(4): 201 - 207.

10. Chang, S. W., Clement, T. P., Simpson, M. J. and Lee, K. K. (2011). Does sea-level rise have an impact on saltwater intrusion? Advances in Water Resources 34(10): 1283 - 1291.

11. Tomaszkiewicz, M., Abou, N. M. and El-Fadel, M. (2014). Development of a groundwater quality index for seawater intrusion in coastal aquifers. Environmental Modelling \& Software 57: 13 - 26.

12. Gasim, M. B., Khalid, N. A., and Muhamad, H. (2015). The influence of tidal activities on water quality of Paka River Terengganu, Malaysia. Malaysian Journal of Analytical Sciences, 19(5): 979 - 990.

13. Toriman, M. E., Gasim, M. B., Ariffin, N. H., Muhamad, H. and Hairoma, N. (2015). The influence of tidal activities on hydrologic variables of Marang River, Terengganu, Malaysia. Malaysian Journal of Analytical Sciences, 19(5): 1099 - 1108.

14. Sharif, S. M., Kusin, F. M., Asha'ari, Z. H. and Aris, A. Z. (2015). Characterization of water quality conditions in the klang river basin, malaysia using self-organizing map and k-means algorithm. Procedia Environmental Sciences, 30: 73-78.

15. Raj, J. K., Tan D. N., and Abdullah W. H. (2009). Cenozoic stratigraphy. In Geology of Peninsular Malaysia. Kuala Lumpur: University of Malaya: pp. $164-168$.

16. Hassan, K. B. (1989). Significance of palynology in late quaternary sediments in Peninsular Malaysia. Geological Society of Malaysia 24: 57 - 66.

17. Saghravani, S. R., Yusoff, I., Wan Md Tahir, W. Z. and Othman, Z. (2015). Estimating recharge based on longterm groundwater table fluctuation monitoring in a shallow aquifer of Malaysian tropical rainforest catchment. Environmental Earth Sciences, 74(6): 4577 - 4587.

18. Feseker, T. (2007). Numerical studies on saltwater intrusion in a coastal aquifer in Northwestern Germany. Hydrogeology Journal, 15(2): 267 - 279.

19. Biglari, A. and Sutherland, J. C. (2015). An a-posteriori Evaluation of principal component analysis-based models for turbulent combustion simulations. Combust and Flame, 162(10): 4025 - 4035.

20. Tantra, R., Oksel, C., Robinson, K. N., Sikora, A., Wang, X. Z. and Wilkins, T. A. (2015). A method for assessing nanomaterial dispersion quality based on principal component analysis of particle size distribution data. Particuology, 22: $30-38$.

21. Parente, A. and Sutherland, J. C. (2013). Principal component analysis of turbulent combustion data: Data preprocessing and manifold sensitivity. Combustion and Flame, 160(2): $340-350$.

22. Kasim, M. K., Juahir, H., Tawnie, I., Azid, A., Saudi, A.S.M., Samsudin, S., Toriman, M.E., Fazli, B.M., and Hasnam, C.N.C. (2015). Environmetric techniques application in water quality assessment: A case study in Linggi River basin. Jurnal Teknologi (Sciences \& Engineering) 74(1): 151-157.

23. Aminu Ibrahim, A., Juahir, H., Toriman, M.E., Mustapha, A., Azid, A. and Isiyaka, H.A. (2015). Assessment of surface water quality using multivariate statistical techniques in the Terengganu River basin. Malaysian Journal of Analytical Sciences, 19(2): 338 - 348.

24. Maritan, L., Holakooei, P. and Mazzoli, C. (2015). Cluster analysis of XRPD data in ancient ceramics: What for? Applied Clay Science, 114: 540 - 549.

25. Shrestha, S. and Kazama, F. (2007). Assessment of surface water quality using multivariate statistical techniques: A case study of the Fuji river basin, Japan. Environmental Modelling \& Software, 22(4): $464-475$.

26. Liu, C. W., Lin, K. H. and Kuo, Y. M. (2003). Application of factor analysis in the assessment of groundwater quality in a blackfoot disease area in Taiwan. Science of the Total Environment. 313(1): 77 - 89.

27. Mokhtar, M., Bahari, I., and Poon, A. (2001). Kualiti air di sekitar kawasan perindustrian Balakong, Lembangan Langat. Malaysian Journal of Analytical Sciences 7(1): 129 - 138. 